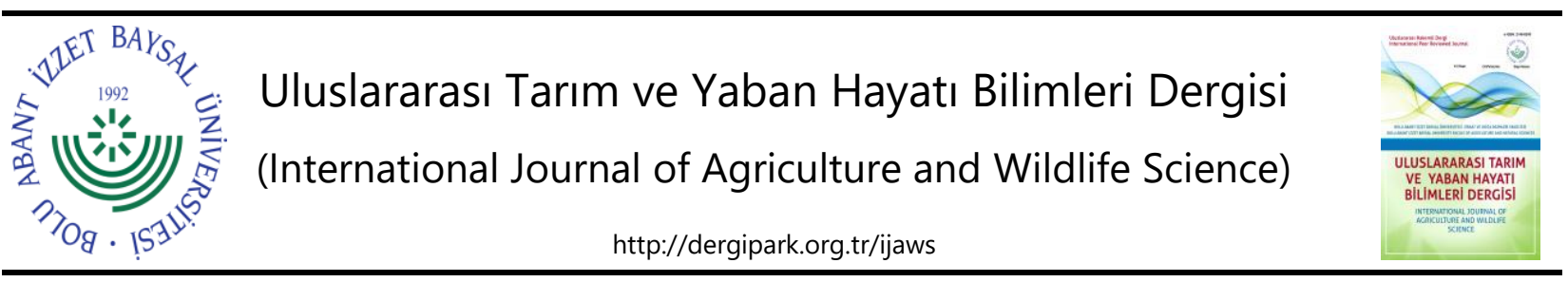

Araştırma Makalesi

\title{
Hıyarda Kök Bakterisi (PGPR) ve Arbusküler Mikorizal Fungus (AMF) Aşılamalarının Farklı Sulama Seviyelerinde Bitki Gelişimi ve Verim Özelliklerine Etkileri
}

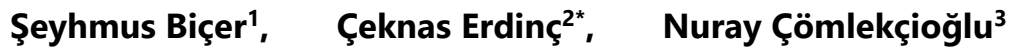 \\ ${ }^{1}$ Yüzüncü Yıl Üniversitesi, Fen Bilimleri Enstitüsü, Bahçe Bitkileri Ana Bilim Dalı, Van \\ ${ }^{2}$ Yüzüncü Yı Üniversitesi, Ziraat Fakültesi, Tarımsal Biyoteknoloji Bölümü, Van \\ ${ }^{3}$ Osmangazi Üniversitesi, Ziraat Fakültesi, Bahçe Bitkileri Bölümü, Eskişehir
}

Geliş tarihi (Received): 08.10.2019 Kabul tarihi (Accepted): 02.03.2020

\begin{abstract}
Anahtar kelimeler:
Hıyar, AMF, PGPR, sulama seviyesi, verim
\end{abstract}

\begin{abstract}
Özet. Bu çalışmada; farklı sulama seviyeleri koşulları altında yetiştirilen sofralık hıyarda, bir ticari kök bakteri karışımı ile yine ticari AMF preparatının bazı bitki gelişim özellikleri ve verime olan etkileri belirlenmeye çalışılmıştır. Çalışma, Eskişehir Osmangazi Üniversitesi, Ziraat Fakültesi deneme arazisi koşullarında gerçekleştirilmiştir. Sulama uygulaması olarak, Class A pan buharlaşma değerinin \%33, $\% 66, \% 100$ ve \%133'ü olmak üzere dört farklı sulama oranı kullanılmıştır. Bakteri ve fungus aşılaması ise kontrol, AMF, PGPR ve AMF+PGPR (karışık inokulasyon) olmak üzere dört şekilde gerçekleştirilmiştir. İki yıl tekrarlanan çalışmanın sonunda sürgün yaş ağırlığı, sürgün kuru ağırlığı, sürgün boyu, sürgün gövde çapı, dekara verim, pazarlanabilir verim, bitki başına meyve sayısı, ortalama meyve ağırığı, bitki başına verim parametreleri incelenmiştir. PGPR aşılamasında toplam verim ve pazarlanabilir verimde birinci yılda en yüksek ortalama elde edilirken (sırasıyla 6.54 ve 6.21 ton $\mathrm{da}^{-1}$ ), ikinci yılda toplam verimde AMF+PGPR aşılaması $\left(8.18\right.$ ton $\left.\mathrm{da}^{-1}\right)$, pazarlanabilir verimde ise AMF aşılamasının (7.83 ton da $^{-1}$ ) en yüksek ortalamaya sahip olduğu görülmüştür. Bunun dışında \%133 sulama seviyesinden hem toplam verim hem de pazarlanabilir verimde her iki yılda da en iyi verim değerleri elde edilmiştir. AMF ve AMF+PGPR aşılamaları bitki gelişim özelliklerinde daha etkili iken, tek başına PGPR aşılamasının söz konusu özelliklerde yeterli olmadığı tespit edilmiştir. Gerek verim özellikleri gerekse bitki gelişimi bakımından sulama uygulamaları arasından genel olarak \%133 seviyesinin başarılı sonuçlar verdiği anlaşılmıştır.
\end{abstract}

*Sorumlu yazar ceknaserdinc@gmail.com

\section{The Effects of Root Bacteria (PGPR) and Arbuscular Mycorrhizal Fungi (AMF) Inoculation on Plant Growth and Yield Properties at Different Irrigation Levels in Cucumber}

\section{Keywords:}

Cucumber, AMF, PGPR, ırrigation level, yield

\begin{abstract}
In this study, it was aimed to determine the effects of a mixture of commercial rhizobacteria and AM fungi on some plant growth characteristics and yield in cucumber grown under distinct irrigation levels. The study was carried out in Eskişehir Osmangazi University, Faculty of Agriculture, experimental land conditions. Four different irrigation rates, 33\%, 66\%, 100\% and $133 \%$, were used as irrigation for the evaporation value of Class $A$ pan. Bacterial and fungal inoculation was performed in four ways as control, AMF, PGPR and AMF + PGPR (mixed inoculation). At the end of the study, which was repeated for two years, the parameters of shoot fresh weight, shoot dry weight, shoot height, shoot diameter, yield, marketable yield, number of fruits per plant, average fruit weight, yield per plant parameters were examined. In the first year, total yield and marketable yield were the highest ( 6.54 and 6.21 tons $\mathrm{da}^{-1}$, respectively) for PGPR inoculation. The highest total yield ( 8.18 tons da $^{-1}$ ) was obtained from application AMF-PGPR inoculation; while the highest marketable yield ( 7.83 tons $\left.^{-1}\right)$ was taken with AMF inoculation in the second year. Additionaly, the best yield values were obtained in both total yield and marketable yield with application of $133 \%$ irrigation level in both years. It was determined that while AMF and AMF + PGPR vaccines were more effective in plant development and PGPR vaccination was not sufficient seperately. As a result, in terms of both yield characteristics and plant development, it was concluded that $133 \%$ level of the irrigation applications was more efficient than others.
\end{abstract}




\section{GiRiş}

Hıyar, yaklaşık olarak 1.8 milyon ton üretim miktarı ile domates, karpuz ve kuru soğandan sonra ülkemizde en fazla yetiştirilen sebze türüdür (TÜiK, 2018). Dünya üretiminde Çin yaklaşık 65 milyon ton ile birinci sırayı alırken, ülkemiz İran ve Rusya'dan sonra gelerek en fazla hıyar üreten dördüncü ülke konumuna ulaşmıştır (Faostat, 2017).

Son yıllarda küresel iklim değişikliğinin biyoçeşitlilik ve bitki örtüsü başta olmak üzere su kaynakları ve tarımsal üretimde de önemli olumsuz etkiler yarattığı görülmektedir. Bu olumsuz etkilerin insan toplumunu sosyal ve ekonomik anlamda da etkilemesi kaçınılmaz görünmektedir (Doğan ve Tüzer, 2011).

Küçükkılavuz (2009)'da Türkiye' de küresel ısınmanın su kaynakları üzerine etkileri hakkında yaptığı çalışmada, iklim değişikliğinin en önemli sonuçlarından birinin su kaynakları üzerinde görüleceği, ülkemizin farklı iklim özelliklerinden dolayı küresel ısınmaya bağlı olarak iklim değişikliğinden çok fazla etkileneceğini bildirmiştir. Özellikle 2017 yılına ait iklim verileri dikkate alındığında; yıllık yağış miktarının ortalamadan \%12 daha düşük olduğu, sıcaklıkla birlikte yağış miktarının da azaldığı rapor edilmiştir (Dikici, 2019). Bu nedenle su kaynaklarının etkin kullanımı, Türkiye gibi tarım ülkeleri için can alıcı öneme sahip konular arasında olacaktır.

Kuraklık stresinin olumsuz etkilerinin azaltılmasında uygulanacak yöntemlerin kolay uygulanabilecek ve düşük maliyetli olması öncelikli hedefler arasındadır. Olumsuz çevre koşullarına tolerant çeşitlerin geliştirilmesi en etkili yöntemlerden biri olarak bilinmektedir. Ancak, kuraklık gibi abiyotik stres koşullarına toleransı yüksek çeşitlerin geliştirilmesi karmaşık olmakla birlikte çok zaman isteyen yöntemlerdir. Bu nedenle gerek verimi artırmak gerekse bitkinin stres koşulları ile başedebilmesini sağlamak amacıyla bitki gelişimini teşvik eden bakterilerin kullanım olanakları ile ilgili araştırmaların sayısı günden güne artış gösrtermektedir (Marulanda ve ark., 2009; Naveed ve ark., 2014).

Genelde rizosferde kolonize olan bitki gelişimini teşvik eden bakteriler (PGPR) arasında Acetobacter, Acinetobacter Achromobacter, Aereobacter, Agrobacterium, Alcaligenes, Artrobacter, Azospirillum, Azotobacter, Bacillus, Burkholderia, Clostridium, Enterobacter, Erwinia, Flavobacterium, Klebsiella, Micrococcus, Pseudomonas, Rhizobium, Serratia ve Xanthomonas cinslerine ait bakteri gruplarının çoğunlukla strese tolarans sağlamada etkin oldukları rapor edilmiştir (Çakmakçı, 2005).

Bitkilerin toprakta bulunan mikroorganizmalarla simbiyotik ilişkiler kurduğu bilinmektedir. Bu yaşam ortaklıklarından en bilineni arbuskular mikorizal funguslar (AMF)'dır (Tüfenkçi ve ark., 2012). Bu fungusların, gerek kök yüzey alanını genişleterek su ve besin alım gücünü artırabildiği ve böylelikle kuraklık problemine çözüm olabileceği ifade edilmektedir (Karipçin ve Şatır, 2016; Budak ve ark., 2017; Çalışkan ve ark., 2017). Bitkileri çevresel stres koşullarına dayanıklı kılan mikorizal mantarlar, kurak alanlarda birtakım mekanizmalarla bitki-su ilişkisini düzenleyerek bitkinin kuraklığa karşı dayanıkııı̆ını arttırmakta, aynı zamanda bitkilerin zararlı patojenlere karşı dayanıklıı̆ını da arttırmaktadır (Doğmuş ve ark., 2006). Ayrıca mikorizaların etkinliklerinin özellikle olumsuz koşullarda (kuraklık, tuzluluk, ağır metal birikimi) daha da fazla ortaya çıktığı da belirlenmiştir (Miransari ve ark., 2008; Gholamhoseini ve ark., 2013).

Tarımsal üretimde biyotik ve abiyotik stres faktörleri, kalite ve verimi önemli derecede etkileyen etkenlerdir. Stres koşullarında yetişen bitkiler; patojenlere karşı yatkınlık, bitki büyümesinde hormonal ve beslenme dengesizliği, fizyolojik bozukluklar gibi birçok zararlı etkenle karşılaşmaktadır. PGPR x AMF kombinasyonun bitkiyi bu etkenlerden koruduğu, bitki gelişimini teşvik ettiği belirtilmektedir. Simbiyotik yaşam tarzının sürdürülebilir tarımda büyük öneme sahip olduğu bildirilmiştir. Ayrıca bu yaşam tarzının hem bitkiyi hem de toprak sağlığını stres koşullarından korudukları ileri sürülmektedir (Nadeem ve ark., 2014).

Bir defada çok su verildiğinde bitki kaybettiği suyu düzenli olarak alamayacağından bitki gelişiminde aksamalar olmaktadır. Su ihtiyacı yüksek olan hıyarın bu nedenle su stresinden önemli derecede etkilendiği bilinmektedir (Wang ve ark., 2012).

Her ne kadar kontrollü şartlarda simbiyotik yaşam tarzının olumlu yönleri ortaya konulmuş olsa da özellikle çok değişken olan tarla koşullarında bu tür çalışmaların yürütülmesi büyük önem taşımaktadır. Böylelikle farkı faktörlerin ve rekabet ortamının da devreye girmesi ile simbiyotik yaşam tarzının özellikle stres koşulları altında ne derece etkili olduğu daha net bir şekilde ortaya konacaktır. Bu amaçla; yürütülen çalışmada kök bakterisi ve arbusküler mikorizal fungus aşılamalarının hıyarda farklı sulama seviyelerinde bitki özellikleri, verim ve kaliteye etkileri belirlenmeye çalışılmıştır.

\section{MATERYAL VE METOT}

Çalışma, Eskişehir Osmangazi Üniversitesi Ziraat Fakültesi deneme alanında 2017 ve 2018 yıllarında yürütülmüştür. Bitkisel materyal olarak bölgede en fazla yetiştirilen Murat $F_{1}$ sofralık hıyar çeşidi kullanılmıştır. PGPR aşılaması için, ticari bir preparat olan Biomarket Tarımsal Biyoteknolojik Ürünler firmasından temin edilen 
Mega Flu (Bacillus megaterium, Pantoea agglomerans ve Pseudomonas fluorescens), AMF inokulasyonu için ise yine ticari bir preparat olan Bioglobal firmasına ait ERS Endo Roots Soluble (Glomus intraradices, Glomus aggregatum, Glomus mosseae, Glomus clarum, Glomus monosporus, Glomus deserticola, Glomus brasillianum, Glomus etunicatum, Gigaspora margarita) kullanılmışır.

\section{Tohum Ekimi ve Yetiştirme Koşulları}

Deneme 2017 ve 2018 yıllarında iki yetiştirme sezonunda yürütülmüştür. Tohum ekimleri 2:1:1 oranında torfperlit-vermikulit karışımından oluşan harca, sırasıyla 22 Haziran 2017-27 Haziran 2018 tarihlerinde yapılmıştır. Fide dikimleri ise 22 Temmuz 2017 ve 27 Temmuz 2018 tarihlerinde gerçekleştirilmiştir. Fideler $0.5 \mathrm{~m}$ sıra arası $0.25 \mathrm{~m}$ sıra üzeri $\left(1 \times 2.5 \mathrm{~m}^{2}\right)$ olacak şekilde çift sıralı olarak dikilmiştir. Blok aralarında $3 \mathrm{~m}$, parsel aralarında tekerrürler arası 1.5 m uygulamalar arasında 2 m boşluk bırakılmıştır. 14 Eylül 2017-21 Eylül 2018 tarihlerinde sonlandırılmıştır.

Deneme, Class A pan buharlaşma değerine göre \%33, \%66, \%100 ve \%133 oranlarında sulama seviyelerinin uygulandığı sulama faktörleri altında, kontrol (bakteri veya fungus inokulasyonu yapılmayan), PGPR, AMF ve PGPR+AMF (karışık inokulasyon) uygulamalarının yer aldığı tesadüf blokları deneme desenine göre 3 tekerrürlü olarak yürütülmüştür.

Fide dikimiyle birlikte her bir bitkiye 35 gr 15:15:15 NPK gübresi verilmiştir. Meyve verim döneminde ise her bir bitkiye 25 gr 15:8:25+(\%3.5 MgO) içerikli NPK gübresi verilmiştir.

Dikimden sonra 2 kez tüm parsellere eşit miktarda sulama yapılmış ve konulu sulamalar 9 gün sonra başlamıştır.

\section{Sulama Uygulaması}

Çalışmada damlama sulama sistemi kullanılmıştır. Su bütçesi için standart buharlaşma kabı (Class A pan) kullanılmıştır. Sulamalar 4 gün aralıklarla güneşin etkin olmadığı saatlerde sulama seviyelerine göre yapılmıştır. Sulamalar IW/CPE oranları dikkate alınarak \%33, \%66, \%100 ve \%133 [IW/CPE; IW: uygulanacak sulama suyu $(\mathrm{mm}) / \mathrm{CPE}$ : Kümülatif Pan buharlaşma miktarı $(\mathrm{mm})]$ olarak gerçekleştirilmiştir.

Sulama seviyeleri için uygulanacak sulama suyu miktarı eşitlik 1 ile hesaplanmış ve belirtilen deneme konuları esas alınarak uygulanmıştır. (Ertek ve Kanber, 2003). Bitki katsayısı (kc) ve kap katsayısı (kp), aşağıda verildiği gibi bitki-kap katsayısı (Kcp) olarak birleştirilmiştir (Ertek ve ark., 2004; Sezen ve ark., 2006).

$$
I=E p \times K c p \times P \times A
$$

I: Uygulanacak sulama suyu miktarı (litre)

A: Parsel alanı $\left(\mathrm{m}^{2}\right)$

P: Islatma alanı yüzdesi (\%85)

Ep: Deneme konularına bağlı olarak Class-A Pandan buharlaşan yığışımlı su miktarı (mm)

Kcp: Bitki ve kap katsayıları (1.25-1.00-0.75-0.50 ve 0.00$)$

Sulama seviyelerinin su tüketiminin hesaplanmasında 2 nolu eşitlik kullanılmıştır (James, 1988).

$$
E T=I+R-D p+C p-R f+\Delta S
$$

Eşitlikte;

ET: Bitki su tüketimi (mm)

I: Uygulanan sulama suyu miktarı (mm)

R: Etkili yağış $(\mathrm{mm})$

Dp: Derine sızma kayıpları $(\mathrm{mm})$

Cp: Kök bölgesi altından kapillar yükselme $(\mathrm{mm})$

Rf: Yüzey akış kayıpları ( $\mathrm{mm}$ )

$\Delta \mathrm{S}$ : Toprak profilindeki (kök bölgesindeki) su içeriği değişimini $(\mathrm{mm})$ ifade etmektedir.

Eşitlikteki, I değeri, sulama suyu ölçümlerinden, R değeri, deneme alanına kurulan portatif meteoroloji istasyonundan, Dp değeri, gravimetrik yöntemle belirlenmiştir. Profilin 90-120 cm'lik katmanında oluşan sızma miktarı derine sızma olarak dikkate alınmışır.

Denemede, sulama suyunun bitki su tüketimini karşılama yüzdesi olarak ifade edilen "bitki su tüketiminde sulamanın payı (Irc)" konulara göre aşağıda verilen 3 nolu eşitlik yardımıyla hesaplanmıştır. (Howell ve ark., 1990). 
Irc: Bitki su tüketiminde sulamanın payı (\%)

I: Mevsimlik sulama suyu (mm)

\section{AMF ve PGPR Aşılaması}

Ticari AMF preparatı (ERS) tohum ekimiyle birlikte her bitkiye 5 gr (25 spor g g $^{-1}$ ) olacak şekilde yetiştirme ortamına verilmiştir.

Bakteri aşılamalarına, sıvı taşıyıcı olarak; Prof. Dr. Recep Kotan tarafından tescil ettirilen BM-MegaFlu (2013 tarih ve 5943 tescil nolu) isimli ticari karışım, bakteri uygulamalarında sıvı taşıyıcı olarak kullanılmıştır (Kotan, 2014). Daldırma yöntemi ile uygulanan PGPR bakterisi için, konsantre şeklinde olan 1 litre Mega Flu 20 litre su ile içerisine $1 \mathrm{~kg}$ toz şeker ilave edilerek karıştırılmıştır. Gölgede bir gün bekletildikten sonra 80 litre su ile toplam hacim 100 litreye tamamlanmıştır. Fide şaşırtma olgunluğuna gelen hıyar fidelerinde daldırma yöntemi kullanarak PGPR ve AMF+PGPR uygulamaları için bakteri aşılaması gerçekleştirilmiştir. Fidelerin bünyelerine PGPR bakterilerinin alımını kolaylaştırmak amacıyla aşılama öncesi sulama yapılmamıştır. PGPR ile muamele edilen her bir viyol bu solüsyon içerisinde 30 dakika bekletilmiştir.

Bakteri uygulaması için karışık inokulasyon (AMF+PGPR) ve PGPR aşılaması, fidelerin hazır halde gelen ticari PGPR solüsyonu içinde dikim öncesi $30 \mathrm{dk}$ süresince bekletilmesi ile gerçekleştirilmiştir.

\section{Çalışmada Incelenen Özellikler ve Verilerin Değerlendirilmesi}

Farklı sulama seviyeleri ile mikrobiyal aşılamanın etkisini belirleyebilmek amacı ile bazı bitkisel özellikler ve verim öğeleri incelenmiştir. Sürgün yaş ve kuru ağırlığı, sürgün boyu ve gövde çapı gibi bitki gelişim kriterlerinin yanı sıra toplam verim, pazarlanabilir verim, bitki başına meyve sayısı, ortalama meyve ağırlığı ve bitki başına verim gibi verim öğeleri de belirlenmiştir.

Araştırmada elde edilen veriler SAS 9.4 (SAS Institute Inc., Cary, NC, USA, 2012) istatistik programı kullanılarak varyans analizi ile $p<0.05$ önemlilik derecesine göre değerlendirilmiştir. Verilerin analizinde istatistiksel olarak önemli bulunan ortalamalar arasındaki farklar Duncan Çoklu Karşılaştırma Testi'ne göre gruplandırılmıştır.

\section{BULGULAR VE TARTIŞMA}

\section{Sulama Miktarı ve Bitki Su Tüketimi}

Denemenin 1. yılında toplam $9 \mathrm{kez} 2$. yılında ise $10 \mathrm{kez}$ konulu sulama yapılmıştır. Sulama suyu ve mevsimlik su tüketim miktarları 1 ve 2 yıl için sırasıyla; 546.48-2202.48 mm ve 423.72-1707.72 mm arasında değişmiştir.

Tarla koşullarında yetiştirilen hıyarda en yüksek bitki su tüketim değeri en yüksek sulama seviyesinde ve en düşük su tüketimi ise sulama seviyesinin en düşük olduğu uygulamalardan hesaplanmıştır. Bitki su tüketiminde sulamanın payı (Irc) konulara göre 1 ve 2 yıl sırasıyla \%71.9-86.5 ve \%62.8-79.8 arasında değişmiştir (Çizelge 1).

Çizelge 1. Sulama seviyelerine göre bitki su tüketim parametreleri.

Table 1. Plant water consumption parameters according to irrigation levels.

\begin{tabular}{lcccccc}
\hline Sulama & \multicolumn{2}{c}{$\mathbf{I}(\mathbf{m m})$} & \multicolumn{2}{c}{ ET $(\mathbf{m m})$} & \multicolumn{2}{c}{ Irc (\%) } \\
\cline { 2 - 7 } Seviyesi & 1.yll & 2. yıl & 1. yıl & 2. yıl & 1. yıl & 2. yıl \\
\hline \%33 & 546.48 & 423.72 & 759.58 & 673.92 & 71.90 & 62.80 \\
\%66 & 1092.96 & 847.44 & 1350.10 & 1150.04 & 80.90 & 73.60 \\
\%100 & 1656.00 & 1284.00 & 1928.90 & 1634.90 & 85.80 & 78.50 \\
\%133 & 2202.48 & 1707.72 & 2544.50 & 2139.72 & 86.50 & 79.80 \\
\hline
\end{tabular}

I: Sulama miktarı, ET: Bitki su tüketimi, Irc: Su tüketiminde sulamanın payı

\section{Bitki Gelişim Özellikleri}

Birinci yıl elde edilen sürgün yaş ağırlığı ortalamaları arasındaki farklılıklarda mikrobiyal aşılama uygulamasının etkisi önemli bulunurken ( $p=0.0010)$, ikinci yıl mikrobiyal aşılama $(p=0.0001)$, sulama seviyeleri $(p=0.0001)$ ve bu iki uygulama arasındaki interaksiyonun $(p=0.0090)$ istatistiki bakımdan önemli olduğu belirlenmiştir (Çizelge 2). Buna göre AMF+PGPR ve AMF uygulamalarının her iki yılda da en yüksek ortalama değerlere ulaştığı görülmüştür. Aynı şekilde her iki yılda da kontrol grubunun en düşük yaş ağırlık ortalamasına sahip olduğu belirlenmiştir (sırasıyla 147.76 ve 137.60 g). Sulama seviyelerinde en düşük sürgün yaş ağırlığı ortalamaları 1. yıl 157.55 g ve 2 . 
yıl $145.80 \mathrm{~g}$ ile \%33 sulama oranında olurken, \%133 sulama seviyesi de sırasıyla 172.81 ve $184.50 \mathrm{~g}$ ile her iki yılın en yüksek ortalamalarına sahip olmuştur.

Çizelge 2' ye göre sürgün kuru ağılığı ortalamaları arasındaki farklılıklar üzerine mikrobiyal aşılama (sırasıyla ( $p=0.0097$ ve $p=0.0001)$ her iki yılda da önemli etki gösterdiği, ancak sulama seviyelerinin sadece ikinci yılda $(p=0.0017)$ etkisinin istatistiki bakımdan önemli olduğu tespit edilmiştir. Özellikle birinci yılda mikrobiyal aşılama uygulamaları kuru madde miktarı bakımından sulama seviyeleri arasında yakın ortalamalara sahip olmuştur. Bu durum sürgün kuru ağırlığında sulama seviyeleri ortalamaları arasında fark yaratsa da bu farkın önemsiz olduğu anlaşılmıştır. Sürgün yaş ağırlı̆ında olduğu gibi her iki yılda da en yüksek ortalamaların AMF ve AMF+PGPR uygulamalarından elde edildiği ve yine bu uygulamaların kontrole göre \%29'a varan artış oranlarına ulaştığı belirlenmiştir. PGPR uygulamaları her iki yılda da en düşük ortalamalara sahip olmuştur (sırasıyla 26.36 ve 29.15 g). Sulama uygulamaları istatistiki olarak önemsiz olmakla birlikte en düşük ortalamaların birinci yıl $28.29 \mathrm{~g}$, ikinci yıl ise $30.10 \mathrm{~g}$ ile \%33 sulama seviyesinde olduğu tespit edilmiştir.

Bitki boyu üzerinde ilk yll sadece mikrobiyal inokulasyon $(p=0.0015)$ ve interaksiyon $(p=0.0074)$ etkili olurken $(p=0.0001)$, ikinci yılda hem mikrobiyal inokulasyon $(p=0.0009)$ hem de sulama seviyelerinin $(p=0.0001)$ etkisinin önemli olduğu saptamıştır. Genel olarak mikrobiyal aşılamanın bitki boyu üzerinde etkisinin olumlu olduğu gözlenirken, yine AMF ve AMF+PGPR uygulamalarının ön plana çıktığı göze çarpmaktadır. Illk yıl \%66'ık sulama seviyesinde AMF uygulaması $115.75 \mathrm{~cm}$ ile ikinci yıl ise $126.83 \mathrm{~cm}$ ile AMF+PGPR inokulasyonları en yüksek ortalama değerlere ulaşmıştır. Sulama seviyelerinde özellikle çalışmanın ikinci yılında \%100 ve \%133 sulama oranlarının en yüksek ortalama ile (sırasıyla 121.66 ve $126.25 \mathrm{~cm}$ ), \%33 ve \%66 oranlarının ise en düşük ortalama ile aynı karşılaştırma grubunda yer aldıkları dikkati çekmektedir (Çizelge 2).

Çalışmanın birinci ve ikinci yılında hem mikrobiyal inokulasyon $(p=0.0157$ ve $p=0.0001)$ hem de sulama seviyelerinin ( $p=0.0489$ ve $p=0.0069)$ gövde çapı üzerindeki etkisinin istatistiki açıdan önemli olduğu tespit edilmiştir (Çizelge 3). Birinci yıl verilerine göre, mikrobiyal aşılama ortalamaları arasında en yüksek gövde çapı değeri AMF $(9.78 \mathrm{~mm}$ ) uygulanmış bitkilerden elde edilirken, \%133 sulama seviyesinin de sulama uygulamasında en yüksek ortalamaya sahip olduğu tespit edilmiştir $(9.65 \mathrm{~mm})$. İkinci yıl verilerinde ise AMF+PGPR (13.03 mm) ve PGPR (12.78 mm) uygulamalarının en yüksek artış miktarı ile aynı karşılaştırma grubunda yer aldığı görülmüştür. Sulama uygulamaları arasında ise en yüksek gövde çapı ortalamasına sahip olan seviyenin \%33 (12.89 mm) olduğu belirlenmiştir. Her iki yılda da \%66 sulama seviyesi sırasıyla 8.40 ve $10.03 \mathrm{~mm}$ ile en düşük ortalama değerlere ulaşmıştır.

Yukarıdaki verilerden de anlaşılacağı üzere sürgün yaş-kuru ağırlıkları ve bitki boyunda AMF ve AMF+PGPR uygulamaları ile daha başarılı sonuçlara ulaşılmıştır. PGPR uygulamasının kontrole göre genel olarak artış sağladığı, ancak AMF ve AMF+PGPR uygulamalarının yaklaşık olarak \%24 ile \%35 oranları arasında artış sağladığı kaydedilmiştir. En düşük sulama seviyesinde AMF ve AMF+PGPR aşılamaları ile birlikte yaş ağırıkta yaklaşık olarak \%44-49 arasında, kuru ağırlıkta ise \%11-16 arasında artış meydana geldiği ve bitki boyunda da buna benzer sonuçların elde edildiği görülmüştür. Çiylez ve Eşitken (2018)'in sürgün yaş ağırlığı üzerine tek bakteri veya mikoriza uygulamalarının olumlu bir etki yaptığını ancak birlikte uygulanmasının etkiyi daha da fazla artıracağını savunmuşlardır. PGPR uygulamasının tek başına kontrole göre etkili olduğu ama AMF ile etkisinin daha iyi ortaya çıktığı görülmüştür. Bu bağlamda AMF ve PGPR aşılamalarının bir arada kullanıldığı çalışmalarda, çalışma sonuçlarımıza benzer şekilde her ikisinin bir arada kullanıldığı uygulamalarrın daha iyi sonuç verdiği ortaya çıkmıştır. Domateste, B. subtilis bakterisinin tohum çimlenmesini (\%35.08), gövde boyunu (\%5.22), kök boyunu (\%21.12), gövde kuru ağırlığını (\%63.50) ve kök kuru ağırlığını (\%54.08) artırdığı belirlenmiştir (Walia ve ark., 2013). Ekici ve ark., (2015) da PGPR kullanımının fide gelişimine katkı sağladığını belirtmişleridir. Samancıoğlu ve ark. (2016); lahana bitkilerinde farklı su kısıtı miktarları ile birlikte stresin artışına paralel olarak bitki gelişiminin olumsuz yönde etkilendiğini, fakat PGPR uygulamaları ile su kısıtının yaratmış olduğu strese karşı tolerans sağlanabileceğini saptamışlardır. Tarla kapasitesinin üstünde olan \%133 sulama oranı, çoğunlukla sürgün yaş ve kuru ağırlıklar ile bitki boyunda olumlu artış sağlamışken, bu parametrelerin \%33 sulama seviyesinden olumsuz etkilendikleri belirlenmiştir. Asraf ve Iram (2005); \%60 su kısıtında fasulye (Phaseolus vulgaris) ve Sesbania aculeata bitkilerinin yaş ve kuru ağırlıkları ile bitki boyunda azalma meydana geldiğini bildirmişlerdir. Yıldıım ve ark., (2015) kıvırcık marulda yaptıkları kısıtı sulama çalışmalarında sulama seviyesinin azalması ile birlikte bitki gelişiminin önemli ölçüde etkilendiğini rapor etmiştir. Abdalla ve El-Khoshiban (2007), kuraklık stresi ile birlikte buğdayda bitki gövde boyunun \%43.58 oranında azaldığını ifade etmişlerdir. Gövde çapında özellikle \%33 ve \%66 sulama seviyelerinde bazı mikrobiyal aşılama uygulamalarııı gövde çapını 2 kat artırdığı saptanmıştır. Bazı araştırmacılara göre, yapılan PGPR uygulamaları ile gövde çapında \%21.49-42.56 arasında değişen oranlarda artış sağlanabileceği belirtilmektedir. Bu doğrultuda, PGPR aşılamasının sebzelerde fide yetiştiriciliğinde kullanılabileceği bildirilmektedir (Kloepper ve ark. 2004, Kokalis-Burelle ve ark., 2006, Turan ve ark., 2014). 
Çizelge 2. Farklı sulama seviyelerinde mikrobiyal aşılamanın bazı bitki gelişimi özelliklerine etkisi.

Table 2. The effect of microbial inoculation on some plant growth characteristics at different irrigation levels.

\begin{tabular}{|c|c|c|c|c|c|c|c|}
\hline \multirow{2}{*}{$\begin{array}{c}\text { Mikrobiyal } \\
\text { aşılama }\end{array}$} & \multirow{2}{*}{$\begin{array}{c}\text { Sulama } \\
(\%)\end{array}$} & \multicolumn{2}{|c|}{ Sürgün yaş ağırlığı (g) } & \multicolumn{2}{|c|}{ Sürgün kuru ağırlığı (g) } & \multicolumn{2}{|c|}{ Bitki boyu (cm) } \\
\hline & & 1.yıl & 2.yıl & 1.yıl & 2.yıl & 1.yıl & 2.yıl \\
\hline \multirow[t]{4}{*}{ Kontrol } & 33 & 148.76 & $110.20 \mathrm{e}$ & 26.86 & 27.30 & $89.66 \mathrm{~cd}$ & 99.33 I \\
\hline & 100 & 145.00 & $148.30 \mathrm{~cd}$ & 27.73 & 28.53 & $83.33 \mathrm{~d}$ & $115.33 \mathrm{e}$ \\
\hline & 133 & 155.80 & $162.30 \mathrm{bc}$ & 30.23 & 31.36 & $114.66 \mathrm{ab}$ & $121.66 \mathrm{~d}$ \\
\hline & Ort. & $147.76 b^{*}$ & $137.60 \mathrm{c}$ & 28.58 bc & $28.42 \mathrm{~b}$ & $96.58 \mathrm{c}$ & $109.16 \mathrm{~b}$ \\
\hline \multirow{4}{*}{ AMF } & 66 & 175.76 & $186.90 \mathrm{ab}$ & 33.13 & 33.50 & $113.33 a b$ & $109.33 \mathrm{~g}$ \\
\hline & 100 & 206.13 & 201.10 a & 37.80 & 41.06 & 124.33 a & $122.00 \mathrm{~d}$ \\
\hline & 133 & 193.40 & 203.50 a & 35.80 & 39.83 & $110.00 \mathrm{a}-\mathrm{c}$ & $111.66 \mathrm{fg}$ \\
\hline & Ort & 182.94 a & 186.90 a & $34.04 \mathrm{ab}$ & $36.54 \mathrm{a}$ & 115.75 a & $111.41 \mathrm{~b}$ \\
\hline \multirow[t]{2}{*}{ PGPR } & 33 & 157.36 & $152.80 \mathrm{~cd}$ & 27.13 & 31.03 & $115.00 \mathrm{ab}$ & $115.33 \mathrm{e}$ \\
\hline & Ort & $145.31 \mathrm{~b}$ & $148.80 \mathrm{~b}$ & $26.36 \mathrm{c}$ & $29.15 b$ & 105.85 bc & $116.58 \mathrm{~b}$ \\
\hline AMF & 33 & 167.60 & $164.00 \mathrm{bc}$ & 29.73 & 30.30 & 108.33 a-d & $125.33 \mathrm{c}$ \\
\hline+ & 66 & 203.26 & $185.20 a b$ & 39.43 & 35.26 & 100.00 b-d & 114.66 ef \\
\hline \multirow[t]{3}{*}{ PGPR } & 100 & 175.13 & $170.00 \mathrm{bc}$ & 33.40 & 32.03 & $113.33 \mathrm{ab}$ & $130.00 \mathrm{~b}$ \\
\hline & 133 & 199.20 & 204.30 a & 37.60 & 37.70 & $118.33 \mathrm{ab}$ & $137.33 \mathrm{a}$ \\
\hline & Ort & $186.30 \mathrm{a}$ & $180.90 \mathrm{a}$ & $35.04 \mathrm{a}$ & $33.82 \mathrm{a}$ & $110.00 \mathrm{ab}$ & $126.83 \mathrm{a}$ \\
\hline Sulama & 33 & 157.55 & $145.80 \mathrm{c}$ & 28.29 & $30.10 \mathrm{~b}$ & 107.08 & $110.66 \mathrm{~b}$ \\
\hline \multirow[t]{3}{*}{ Ort. } & 66 & 169.48 & $161.70 \mathrm{~b}$ & 32.59 & $30.34 \mathrm{~b}$ & 105.5 & $105.41 \mathrm{~b}$ \\
\hline & 100 & 162.47 & $162.20 \mathrm{~b}$ & 30.58 & $31.90 \mathrm{~b}$ & 106.83 & $121.66 \mathrm{a}$ \\
\hline & 133 & 172.81 & $184.50 \mathrm{a}$ & 32.56 & $35.60 \mathrm{a}$ & 108.5 & $126.25 \mathrm{a}$ \\
\hline
\end{tabular}

*:Aynı harfle gösterilen rakamlar arasında \%5 önem seviyesine göre fark yoktur.

\section{Verim Özellikleri}

Kök bakterisi ve arbusküler mikorizal fungus aşılamalarının birinci ve ikinci yılda dekara verim üzerine etkisi istatistiki bakımdan önemli bulunmuştur (sırasıyla $p=0.0001$ ve $p=0.0001$ ). Dekara verimin en yüksek olduğu

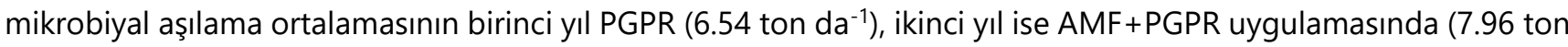
$\mathrm{da}^{-1}$ ) olduğu tespit edilmiştir. En düşük ortalama verimin ise ilk yıl kontrol grubunda, ikinci yıl da kontrol ve PGPR uygulamasında olduğu gözlemlenmiştir. Sulama seviyeleri de her iki yetiştirme döneminde verim üzerine istatistiksel olarak önemli etki yapmıştır (sırasıyla $p=0.0001$ ve $p=0.0001$ ). Çalışmanın iki yılında da benzer olarak en yüksek verim ortalamaları \%100 ve \%133 sulama seviyelerinden elde edilirken, $\% 33$ ve \%66 sulama oranlarının aynı karşılaştırma grubunda yer alarak en düşük verim değerlerine sahip oldukları tespit edilmiştir (Çizelge 3). Mikrobiyal aşılama ve sulama seviyeleri arasındaki etkileşimin birnci ve ikinci yıl önemli çıktığı görülmüştür (sırasıyla $p=0.033$ ve $p=0.0301$ ). Bu bağlamda birinci yılda en yüksek verim değeri AMF+PGPR aşılaması ile \%133 sulama seviyesinden elde edilmiştir (8.23 ton da $\left.^{-1}\right)$. İkinci yılda ise bu durumun AMF ile \%133 sulama seviyesi

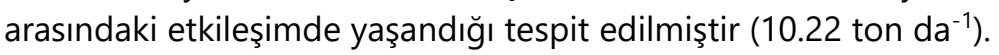

Pazarlanabilir verim miktarı üzerine, iki yetiştirme döneminde de hem mikrobiyal inokulasyon (sırasıyla $p=0.033$ ve $p=0.0001$ ) hem de sulama seviyelerinin (sırasıyla $p=0.0001$ ve $p=0.0001$ ) etkisinin önemli olduğu belirlenmiştir. Ayrıca mikrobiyal aşılama ve sulama seviyeleri arasındaki interaksiyonun ikinci yıl etkisinin önemli olduğu gözlemlenmiştir ( $p=0.030)$. Pazarlanabilir verim miktarı dekara verim miktarıly paralellik göstermiş olup birinci yıl verilerinde olduğu gibi mikrobiyal inokulasyon ortalamasının en yüksek PGPR (6.21 ton da ${ }^{-1}$ ) uygulamalarında olduğu tespit edilmiştir. Sulama seviyeleri arasında ise en fazla pazarlanabilir verim miktarının \%133 (6.69 ton da$\left.{ }^{1}\right)^{\prime}$ lük sulama seviyesinde olduğu tespit edilmiştir. İkinci yıl verilerine göre en yüksek pazarlanabilir verim miktarının mikrobiyal inokulasyon ortalamasının AMF (7.83 ton da $\left.{ }^{-1}\right)$ ve AMF+PGPR (7.77 ton da $\left.{ }^{-1}\right)$ uygulamalarında olduğu tespit edilmiştir. Sulama seviyeleri ortalaması arasında en fazla pazarlanabilir verim miktarının \%133 (7.57 ton da 1) 'lük sulama seviyesinde sulanan bitkilerde olduğu belirlenmiştir.

Dekara verimde tarla kapasitesi sulama koşulları (\%100) dikkate alındığında, mikrobiyal aşılama uygulamalarının kendi içinde sulama seviyelerindeki değişimlerde, özellikle ikinci yılda \%33 ve \%66 sulama oranında kontrolde yaklaşık verimde \%36-38 azalma yaşanırken, AMF+PGPR aşılamasında bu oranın \%13-19 seviyelerine indiği göze çarpmaktadır. Özellikle ikinci yılda \%100 sulama seviyesi temel alınarak hesaplanan değişim oranlarında mikrobiyal aşılamanın kontrolden daha iyi oranları yakaladığı görülebilmektedir (Şekil 1). Her ne kadar pazarlanabilir verimde bazı azalışlar yaşansa da mikrobiyal aşılama uygulamalarının dekara verimde olduğu gibi, stres koşulları dâhil olmak üzere pazarlanabilir verim artışındaki etkisinin azımsanamayacak derecede etkili olduğu söylenebilir (Şekil 2). 
Biçer ve ark., Hıyarda Kök Bakterisi (PGPR) ve Arbusküler Mikorizal Fungus (AMF) Aşılamalarının Farklı Sulama Seviyelerinde Bitki Gelişimi ve Verim Özelliklerine Etkileri

Çizelge 3. Farklı sulama seviyelerinde mikrobiyal aşılamanın bazı bitki gelişimi ve verim özelliklerine etkisi.

Table 3. The effect of microbial inoculation on some plant growth and yield characteristics at different irrigation levels.

\begin{tabular}{|c|c|c|c|c|c|c|c|}
\hline \multirow{2}{*}{$\begin{array}{c}\text { Mikrobiyal } \\
\text { Aşılama }\end{array}$} & \multirow{2}{*}{$\begin{array}{c}\text { Sulama } \\
(\%)\end{array}$} & \multicolumn{2}{|c|}{ Gövde çapı (mm) } & \multicolumn{2}{|c|}{ Dekara verim (ton $\mathrm{da}^{-1}$ ) } & \multicolumn{2}{|c|}{ Pazarlanabilir verim (ton $\mathrm{da}^{-1}$ ) } \\
\hline & & 1.yıl & 2.yıl & 1.yıl & 2.yıl & 1.yıl & 2.yıl \\
\hline \multirow[t]{4}{*}{ Kontrol } & 33 & 8.99 & 7.95 & $4.30 \mathrm{de}$ & $4.35 \mathrm{~g}$ & 4.09 & $4.13 \mathrm{~g}$ \\
\hline & 100 & 8.45 & 8.95 & $5.76 \mathrm{~b}-\mathrm{e}$ & $6.87 \mathrm{c}-\mathrm{e}$ & 5.47 & $6.53 \mathrm{c}-\mathrm{e}$ \\
\hline & 133 & 9.17 & 11.44 & $5.54 \mathrm{~b}-\mathrm{e}$ & $7.06 \mathrm{~cd}$ & 5.27 & $6.71 \mathrm{~cd}$ \\
\hline & Ort. & $8.61 b^{*}$ & $8.94 \mathrm{c}$ & $5.12 \mathrm{~b}$ & $5.62 \mathrm{~b}$ & $4.86 b^{*}$ & $5.34 \mathrm{~b}$ \\
\hline \multirow{4}{*}{ AMF } & 66 & 8.66 & 10.68 & $4.10 \mathrm{e}$ & 6.94 c-e & 3.90 & 6.59 c-e \\
\hline & 100 & 9.21 & 12.24 & 6.26 a-e & $9.29 \mathrm{ab}$ & 5.95 & $8.82 \mathrm{ab}$ \\
\hline & 133 & 10.95 & 10.62 & $6.63 a-d$ & $10.22 \mathrm{a}$ & 6.30 & $9.71 \mathrm{a}$ \\
\hline & Ort & $9.78 \mathrm{a}$ & $11.05 \mathrm{~b}$ & $5.47 \mathrm{ab}$ & $8.24 \mathrm{a}$ & $5.20 a b$ & $7.83 \mathrm{a}$ \\
\hline \multirow[t]{2}{*}{ PGPR } & 33 & 8.85 & 16.89 & $5.37 \mathrm{c}-\mathrm{e}$ & $5.24 \mathrm{e}-\mathrm{g}$ & 5.10 & $4.97 \mathrm{e}-\mathrm{g}$ \\
\hline & Ort & 8.18 b & $12.78 \mathrm{a}$ & $6.54 \mathrm{a}$ & $5.33 \mathrm{~b}$ & $6.21 \mathrm{a}$ & $5.06 \mathrm{~b}$ \\
\hline AMF & 33 & 8.28 & 16.05 & $4.91 \mathrm{c}-\mathrm{e}$ & $7.16 \mathrm{~cd}$ & 4.66 & $6.80 \mathrm{~cd}$ \\
\hline+ & 66 & 8.22 & 11.82 & $4.36 \mathrm{de}$ & 7.66 bc & 4.14 & $7.27 \mathrm{bc}$ \\
\hline \multirow[t]{3}{*}{ PGPR } & 100 & 8.64 & 11.72 & 6.99 a-c & $8.85 \mathrm{ab}$ & 6.64 & $8.41 \mathrm{ab}$ \\
\hline & 133 & 11.13 & 12.55 & 8.23 a & $9.03 \mathrm{ab}$ & 7.81 & $8.58 a b$ \\
\hline & Ort & $9.07 \mathrm{ab}$ & $13.03 \mathrm{a}$ & $6.12 \mathrm{ab}$ & $8.18 \mathrm{a}$ & $5.81 \mathrm{ab}$ & $7.77 \mathrm{a}$ \\
\hline Sulama & 33 & $9.10 \mathrm{ab}$ & $12.89 \mathrm{a}$ & $4.87 \mathrm{~b}$ & $5.82 \mathrm{~b}$ & $4.63 \mathrm{~b}$ & $5.52 \mathrm{~b}$ \\
\hline \multirow[t]{3}{*}{ Ort. } & 66 & $8.40 \mathrm{~b}$ & $10.03 \mathrm{c}$ & 4.66 b & $6.09 \mathrm{~b}$ & 4.42 b & $5.78 b$ \\
\hline & 100 & $8.49 b$ & $11.13 \mathrm{bc}$ & $6.69 a$ & $7.50 \mathrm{a}$ & $6.35 a$ & 7.13 a \\
\hline & 133 & $9.65 \mathrm{a}$ & $11.77 \mathrm{ab}$ & $7.04 \mathrm{a}$ & $7.96 \mathrm{a}$ & $6.69 \mathrm{a}$ & $7.57 \mathrm{a}$ \\
\hline
\end{tabular}

*:Aynı harfle gösterilen rakamlar arasında \%5 önem seviyesine göre fark yoktur.

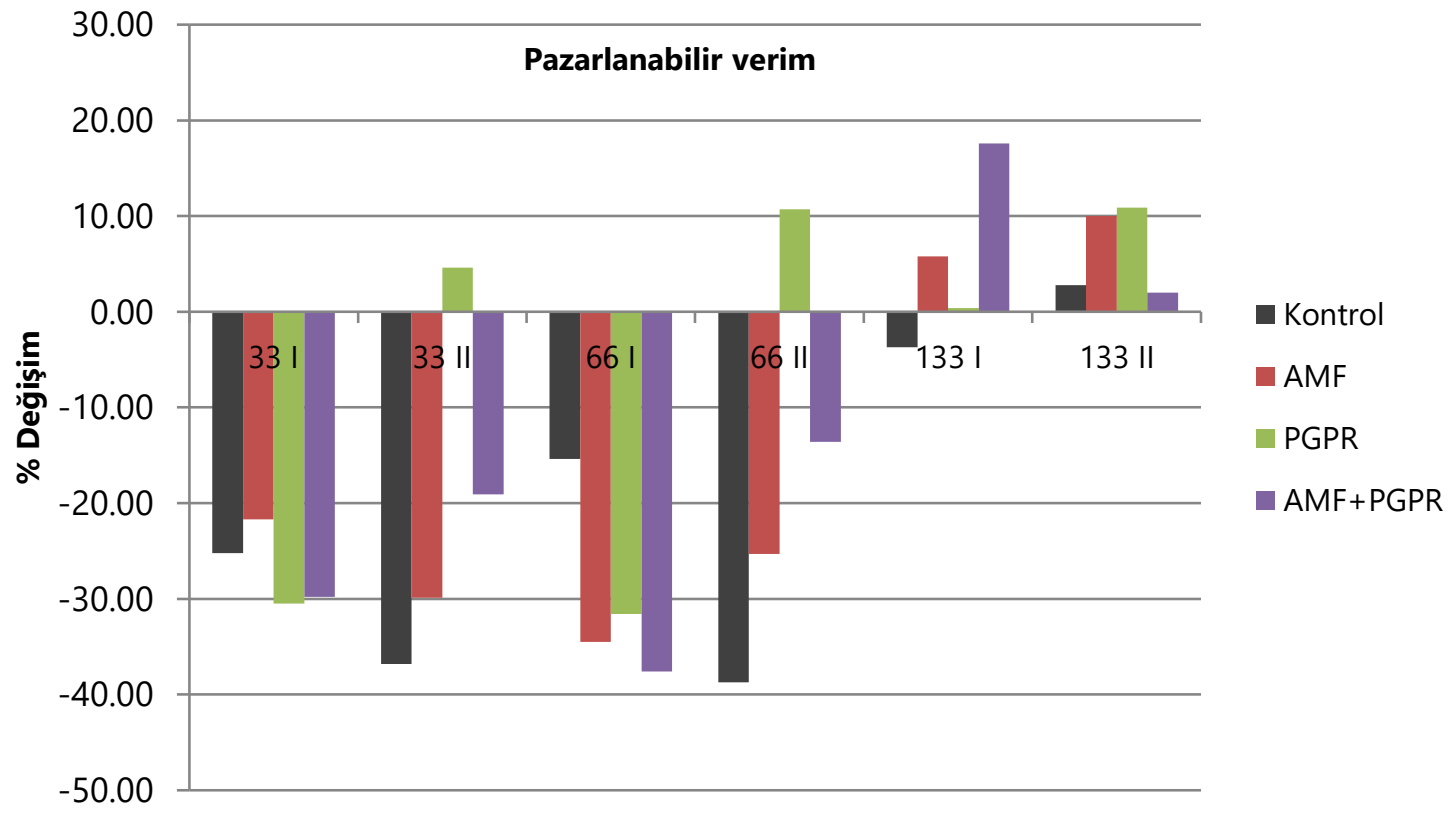

Şekil 1. Farklı sulama seviyelerinde \%100 sulamaya göre pazarlanabilir verim bakımından mikrobiyal aşılama uygulamaları arasındaki değişim oranları (\%).

Figure 1. Change rates among microbial inoculations in different irrigation levels in terms of marketable yield compared to $100 \%$ irrigation. 


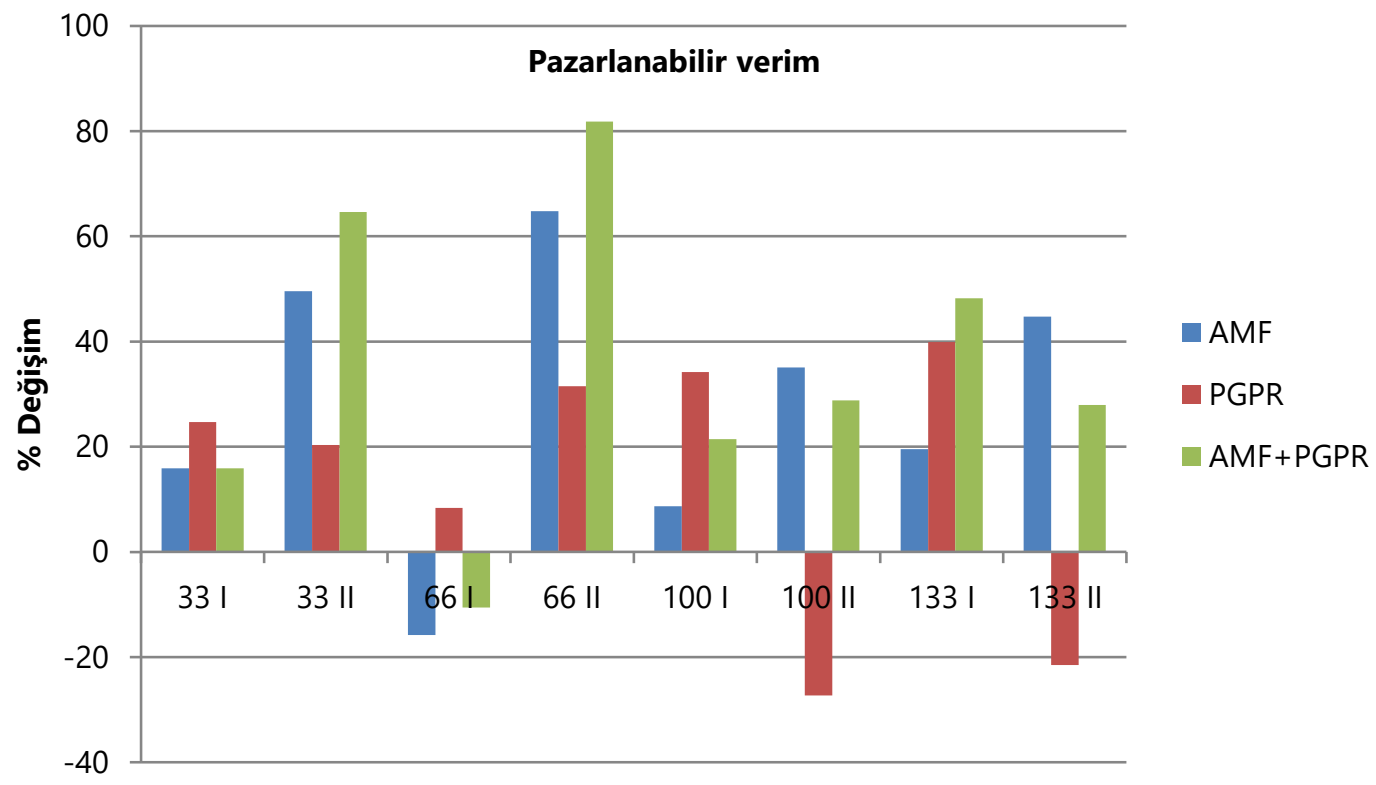

Şekil 2. Mikrobiyal aşılama uygulamalarında pazarlanabilir verim değerlerinin kontrole göre değişim oranları (\%). Figure 2. Change rates of marketable yield in microbial inoculations compared to control.

Bitki başına verimde birinci yıl mikrobiyal aşılama $(p=0.0001)$ ve sulama seviyelerinin $(p=0.029)$ etkisi önemli bulunmuştur. Bu bakımdan, $455.07 \mathrm{~g}$ ile AMF+PGPR ve $478.01 \mathrm{~g}$ ile AMF uygulamaları en yüksek bitki başına verim ortalamalarına sahip olmuşlardır. En düşük ortalamaların ise PGPR ve kontrol uygulamalarından elde edildiği belirlenmiştir (sırasıyla 350.86 ve $356.86 \mathrm{~g})$. İkinci yılda mikrobiyal aşılama $(p=0.0001)$, sulama seviyeleri $(p=0.0001)$ ve interaksiyon etkisinin $(p=0.007)$ önemli olduğu görülmüştür. Mikrobiyal aşılama uygulamaları arasında en yüksek ortalama AMF inokulasyonundan $(838.34 \mathrm{~g})$, en düşük ortalama ise PGPR aşılamasından elde edilmiştir (498.17 g). Sulama seviyelerinde birinci yıl \%100, ikinci yıl ise \%133 sulama miktarı en iyi artışın yaşandığı seviyeler olup, \%66 sulama seviyesinin, her iki yılda da en az bitki başına verim rakamlarına ulaşılan uygulama olduğu tespit edilmiştir. İnteraksiyon etkisinde, AMF ve \%133 sulama seviyesinin bitki başına $991.46 \mathrm{~g}$ ile en yüksek verim rakamlarına sahip olduğu ortaya çıkmıştır (Çizelge 4).

Mikrobiyal inokulasyon uygulamalarının ortalama meyve ağılığına etkisi birinci ve ikinci yılda istatistiksel olarak önemsiz bulunmuştur. Ancak sulama seviyeleri arasındaki farklılıkların ikinci yılda önemli etki yarattığı gözlemlenmiştir ( $p=0.0029$ ). Bu verilere göre ikinci yılla \%133 sulama seviyesinin (100.42 g) en yüksek ortalama meyve ağırlığına sahip olduğu tespit edilmiştir. En düşük ortalama meyve ağırlığı ise \%66 (96.16 g) sulama seviyesinden elde edilmiştir (Çizelge 4).

Bitki başına meyve sayısında birinci ve ikinci yıl hem mikrobiyal aşılama (sırasıyla $p=0.0433$ ve $p=0.0001$ ) hem de sulama seviyeleri (sırasıyla $p=0.0001$ ve $p=0.0076$ ) arasındaki farklılıkların istatistiki olarak önemli bulunduğu saptanmıştır. Birinci yıl mikrobiyal inokulasyon ortalamasının en yüksek AMF (4.78 adet) ve AMF+PGPR (4.63 adet) uygulamalarında olduğu tespit edilmiştir. Sulama seviyeleri arasında ise \%33'lük (4.55 adet) sulamanın en fazla bitki başına meyve sayısı ortalamasına sahip olduğu belirlenmiştir. ìkinci yıl verilerine göre mikrobiyal inokulasyon uygulanan bitkilerden elde edilen bitki başına meyve sayısı ortalamasının en yüksek AMF (9.19 adet) uygulamasında olduğu ortaya çıkmıştır. Sulama seviyeleri bakımından ise en yüksek ortalamanın \%100 (6.32 adet) sulama seviyesinde olduğu belirlenmiştir. Sulama seviyeleri ve mikrobiyal inokulasyon arasındaki birinci $(p=0.0156)$ ve ikinci yıldaki $(p=0.0024)$ interaksiyona göre AMF ile birlikte \%33 sulama seviyesinin ön plana çıktığı dikkati çekmiş̧ir. Mikrobiyal aşılama uygulamalarının kontrol grubunda \%66 sulama seviyesinin en düşük ortalamalara ulaştığı kaydedilmiştir (Çizelge 4).

Mikrobiyal aşılamanın hemen hemen tüm sulama seviyelerinde kontrole göre dekara verim ve pazarlanabilir verimde artış sağladığı önemli bir husus olarak ortaya çıkmaktadır. İlk yıl PGPR uygulaması özellikle \%33 sulama seviyesinde yaklaşık \%25 verim artışı sağlamıştır. PGPR bitki büyümesinde direk etkiye sahip olan indolasetik asit (IAA), sitokinin, auxin, giberellik asit gibi hormonların üretilmesi veya stres altında oluşan zararlı etilen seviyesinin azaltılmasında önemli rol oynamaktadır (Narula ve ark., 2006; Saleem ve ark., 2007; van Loon, 2007). Söz konusu mekanizmalarla PGPR tohum çimlenmesi ve sürgün gelişiminde (Hassan ve ark., 2019) artı̧̧ sağlayabilir, ayrıca kuraklık ve tuzluluk gibi abiyotik stres koşullarında da (Lucy ve ark., 2004) bitki toleransını arttırabilir. Bu tolerans mekanizmasının PGPR tarafından salgılanan ACC-deaminase enziminin stres koşullarında olumsuz etki yaratan 
etileni baskılaması ile meydana geldiği bildirilmektedir (Arshad ve ark., 2008). Bu bağlamda kısıtlı sulama koşullarında PGPR kullanımının verim parametrelerinde artış sağladığı birçok araştırmada vurgulanmıştır (Ghanbari Zarmehri ve ark., 2013; Naseri ve ark., 2013; Sahin ve ark., 2015; Le ve ark., 2018). Aslantaş ve ark. (2007), Karlıdağ ve ark. (2007) ve Karthikean ve ark. (2010) da farklı türlerde yaptıkları birçok çalışmada PGPR kullanımının verimi olumlu yönde etkilediğini bildirmişlerdir. İkinci yıl AMF+PGPR uygulamasının kontrole göre değişim oranının aynı sulama seviyesinde \%64 ve yine \%66 sulama seviyesinde ise \%81 olduğu tespit edilmiştir. Bakr ve ark. (2016), domateste \%50 sulama koşullarında AMF inokulasyonu yapılan bitkilerde kontrole göre pazarlanabilir verimin yaklaşık \%50 oranının üstüne çıktığını, bu durumun özellikle stres koşullarında AMF'nin su kullanım etkinliğini artırmasından kaynaklandığını belirtmişlerdir. Candido ve ark. (2015) yalnız AMF ve AMF+PGPR kullanımının gerek bitki gelişiminde gerekse verimde artış sağladığını belirtmişlerdir. Bona ve ark. (2018), AMF ve PGPR uygulamalarının yalnız veya karışık uygulamalarının bitkide farklı etkiler meydana getirdiğini ve bu mikroorganizmaların kullanııması ile meyve kalitesinin artıılabileceğini açıklamışlardır.

Çizelge 4. Farklı sulama seviyelerinde mikrobiyal aşılamanın bazı verim özelliklerine etkisi.

Table 4. The effect of microbial inoculation on some yield characteristics at different irrigation levels.

\begin{tabular}{|c|c|c|c|c|c|c|c|}
\hline \multirow[t]{2}{*}{$\begin{array}{l}\text { Mikrobiyal } \\
\text { aşılama }\end{array}$} & \multirow[t]{2}{*}{$\begin{array}{l}\text { Sulama } \\
\text { (\%) }\end{array}$} & \multicolumn{2}{|c|}{$\begin{array}{c}\text { Bitki başına verim } \\
\text { (g) }\end{array}$} & \multicolumn{2}{|c|}{$\begin{array}{c}\text { Ortalama meyve ağırlığı } \\
\text { (g) }\end{array}$} & \multicolumn{2}{|c|}{$\begin{array}{c}\text { Bitki başına meyve sayısı } \\
\text { (Adet) }\end{array}$} \\
\hline & & 1.yıl & 2.yıl & 1.yıl & 2.yıl & 1.yıl & 2.yıl \\
\hline \multirow{3}{*}{ Kontrol } & 66 & 294.41 & $356.58 \mathrm{~h}$ & 92.86 & 97.16 & $3.16 \mathrm{j}$ & $2.66 \mathrm{f}$ \\
\hline & 100 & 470.63 & 707.82 c-e & 87.38 & 97.21 & 3.19 ij & $5.21 \mathrm{c}-\mathrm{e}$ \\
\hline & 133 & 322.28 & $821.73 b c$ & 95.98 & 101.14 & $3.84 \mathrm{~h}$ & $6.03 \mathrm{~b}-\mathrm{d}$ \\
\hline \multirow[t]{5}{*}{ AMF } & 33 & 566.36 & $640.06 \mathrm{de}$ & 96.88 & 99.81 & $5.58 \mathrm{a}$ & $10.25 \mathrm{a}$ \\
\hline & 66 & 407.81 & $771.92 \mathrm{~cd}$ & 95.15 & 97.48 & $4.05 \mathrm{f}$ & $7.16 \mathrm{bc}$ \\
\hline & 100 & 558.32 & $949.92 \mathrm{ab}$ & 102.24 & 103.62 & $5.43 \mathrm{~b}$ & $11.73 \mathrm{a}$ \\
\hline & 133 & 379.54 & $991.46 \mathrm{a}$ & 93.47 & 98.77 & $4.05 \mathrm{f}$ & $7.50 \mathrm{~b}$ \\
\hline & Ort & $478.01 \mathrm{a}$ & $838.34 \mathrm{a}$ & 96.93 & 99.92 & $4.78 \mathrm{a}$ & $9.19 \mathrm{a}$ \\
\hline \multirow{2}{*}{ PGPR } & 133 & 313.71 & $624.76 \mathrm{~d}-\mathrm{f}$ & 88.71 & 101.56 & 3.22 I & 3.66 ef \\
\hline & Ort & $350.86 \mathrm{~b}$ & $498.17 \mathrm{c}$ & 92.15 & 98.22 & $3.51 \mathrm{~b}$ & $3.44 \mathrm{c}$ \\
\hline AMF & 33 & 472.24 & $562.46 \mathrm{e}-\mathrm{f}$ & 98.38 & 99.26 & $4.94 \mathrm{~d}$ & $4.73 d-f$ \\
\hline+ & 66 & 424.66 & $612.81 \mathrm{~d}-\mathrm{f}$ & 98.20 & 93.43 & $4.07 \mathrm{f}$ & $4.66 d-f$ \\
\hline \multirow[t]{3}{*}{ PGPR } & 100 & 424.28 & $602.98 d-f$ & 90.56 & 97.99 & $4.17 \mathrm{e}$ & $4.91 \mathrm{~d}-\mathrm{f}$ \\
\hline & 133 & 499.09 & 719.72 c-e & 92.24 & 100.22 & $5.34 \mathrm{c}$ & $4.65 d-f$ \\
\hline & Ort & $455.07 \mathrm{a}$ & $624.50 \mathrm{~b}$ & 94.84 & 97.72 & $4.63 \mathrm{a}$ & $4.74 \mathrm{~b}$ \\
\hline Sulama & 33 & $427.09 \mathrm{ab}$ & $521.70 \mathrm{c}$ & 95.25 & $97.20 \mathrm{bc}$ & $4.55 \mathrm{a}$ & $5.26 \mathrm{~b}$ \\
\hline \multirow[t]{2}{*}{ Ort. } & 66 & $371.38 b$ & $544.48 c$ & 94.50 & $96.16 \mathrm{c}$ & $3.80 \mathrm{~b}$ & $4.48 \mathrm{~b}$ \\
\hline & 100 & $463.67 \mathrm{a}$ & $681.93 \mathrm{~b}$ & 93.74 & $99.54 \mathrm{ab}$ & $3.97 \mathrm{ab}$ & $6.32 \mathrm{a}$ \\
\hline
\end{tabular}

*:Aynı harfle gösterilen rakamlar arasında \%5 önem seviyesine göre fark yoktur.

Sulama seviyeleri ve mikrobiyal aşılamanın ortalama meyve ağırlığında ciddi bir etkisinin olmadığı gözlemlenmiştir (Çizelge 4). Ortalama meyve sayısı dışındaki tüm verim kriterlerinde özellikle ikinci yılda çalışmanın ilk yılına göre AMF inokulasyonunda belirgin artış yaşandığı görülmektedir (Çizelge 3 ve 4). AMF infekteli bitkilerin kurak koşullarda kök bölgesinde daha yüksek hidrolik iletkenliğe sahip olduğu ve bu durumun su alımında ve dolayısıyla verimde etkili olduğu bildirilmektedir (Barrios-Masias ve ark., 2015). Aynı zamanda bitki başına meyve sayısında her iki yılda da AMF'nin yalnız uygulandığı \%33 sulama seviyesinin \%100 oranında sulama ile eşdeğer seviyelere ulaştığı dikkat çekmektedir. Fungus inokulasyonunun domateste çiçeklenmeyi olumlu etkilediği (Subramanian ve ark., 2006), bu durumunda meyve veren çiçek sayısını artırdığı (Conversa ve ark., 2013) ve genel olarak AMF'nin tarımsal ekosistemlerde kısıtı sulama koşullarında bitki toleransında önemli rol oynadığı rapor edilmektedir (Bowles ve ark., 2016). Kontrol parsellerinde \%33 ve 66 sulama seviyelerinin bitki başına meyve sayısı bakımından geri planda kaldığı görülürken, PGPR ve AMF+PGPR aşılamalarının olduğu sulama seviyelerinde özellikle söz konusu sulama oranlarında böyle bir durumdan söz edilemediği gözlemlenmektedir. Bunun dışında, \%33 sulama seviyesinin her iki yıl için \%100 sulamaya göre AMF inokulasyonunda yaklaşık \%52-60, PGPR aşılamasında \%2-10 ve AMF+PGPR uygulamasında ise \%34-39 oranları arasında bitki başına verimi artırdığı görülmektedir (Çizelge 4). Bolandnazar ve ark. (2007) ile Rozpadek ve ark. (2016) soğanda, Karipçin ve Şatır (2016), marulda, Cakmakci ve ark. (2017) kavunda benzer şekilde mikorizal inokulasyonun kısıtlı sulama koşulları altında etkili olduğunu belirtmişlerdir. 


\section{SONUÇ}

Bu çalışmanın sonucunda temel olarak kök bakterisi ve arbusküler mikorizal fungus aşılamalarının hıyarda farklı sulama seviyelerinde bitki gelişimi ve verim özelliklerine olumlu etkilerinin olduğu gözlenmiştir. Çalışmanın her iki yılında gerek bitki gelişim kriterleri gerekse verim özelliklerinde, AMF ve AMF+PGPR uygulamalarından daha etkili sonuçlar alındığı, ancak PGPR aşılamasının da yine kontrole göre etkin olduğu anlaşılmıştır. Ayrıca, bu mikroorganizmaların kısıtlı sulamada özellikle \%33 sulama seviyesinde inokulasyon yapılmamış kontrol bitkilerine göre hemen hemen incelenen tüm özelliklerde artış sağladığı görülmüştür. Kuraklık, ülkemizin ve dünyanın boğuştuğu küresel boyuttaki en önemli problemlerden biri olarak görülmektedir. Bu nedenle gelecekte tarımsal ekosistemler için sürdürülebilir nitelikte çevre dostu üretim tekniklerinin hayata geçirilmesi kaçınılmazdır. Bu bağlamda bitki beslemede olumlu etkiler yaratacağı düşünülen mikroorganizmalar tarımsal üretim sistemlerine dahil edilmesi ile daha etkin sulama programlarının kullanılabileceği ve böylelikle ülkemizin su kaynaklarının korunmasına katkı sunulacağı inancındayız.

\section{ÇIKAR ÇATIŞMASI}

Yazarlar arasında herhangi bir çıkar çatışması mevcut değildir.

\section{YAZAR KATKISI}

Şeyhmus BiÇER: Arazi çalışmalarının yürütülmesi ve laboratuvar analizlerinin gerçekleştirilmesi Çeknas ERDiNÇ: İstatistik analizlerin yapılması, makalenin yazılması

Nuray ÇÖMLEKÇiOĞLU: Arazi çalışmalarının yürütülmesi ve laboratuvar analizlerinin gerçekleştirilmesi

\section{TEŞEKKÜR}

Bu çalışma Van Yüzüncü Yıl Üniversitesi, Bilimsel Araştırma Projeleri Koordinasyon Birimi tarafından FDK-20176015 nolu doktora tez projesi ile desteklenmiştir. PGPR inokulum kaynağı için Atatürk Üniversitesi, Ziraat Fakültesi, Bitki Koruma Bölümü öğretim üyesi Prof. Dr. Recep KOTAN'a, arazi çalışmalarının yürütülmesi için deneme alanı sağlayan Eskişehir Osmangazi Üniversitesi Ziraat Fakültesi, Bahçe Bitkileri Bölüm Başkanlığı́na teşekkür ederiz.

\section{KAYNAKLAR}

Abdalla, M. M., \& El-Khoshıban, N. H. (2007). The influence of water stress on growth, relative water content, photosynthetic pigments, some metabolic and hormonal contents of two Triticium aestivum cultivars. Journal of Applied Sciences Research, 3(12), 2062-2074.

Arshad, M., Shaharoona, B., \& Mahmood, T. (2008). Inoculation with Pseudomonas spp. containing ACC-deaminase partially eliminates the effects of drought stress on growth, yield, and ripening of pea (Pisum sativum L.). Pedosphere, 18(5), 611-620.

Aslantaş, R., Çakmakçı, R., \& Sahin, F. (2007). Effect of plant growth promoting rhizobacteria on young apple tree growth and fruit yield under orchard conditions. Scientia Horticulturae, 111, 371-377.

Asraf, M., \& Iram, A. (2005). Drought stress induced changes in some organic substances in nodules and other plant parts of two potential legumes differing in salt tolerance. Flora, 200, 535-546.

Bakr, J., Daood, H. G., Pék, Z., Helyes, L. \& Posta, K. (2016). Yield and quality of mycorrhized processing tomato under water scarcity. Applied Ecology and Environmental Research, 15(1), 401-413.

Barrios-Masias, F. H., Knipfer, T., \& McElrone, A. (2015). Differential responses of grapevine rootstocks to water stress are associated with adjustments in fine root hydraulic physiology and suberization. Journal of Experimental Botany, 66, 6069-6078.

Bolandnazar, S., Aliasgarzad, N., Neishabury, M. R., \& Chaparzadeh, N. (2007). Mycorrhizal colonization improves onion (Allium cepa L.) yield and water use efficiency under water deficit condition. Scientia Horticulturae, 114, 11-15.

Bona, E., Todeschini, V., Cantamessa, S., Cesaro, P., Copetta, A., Lingua, G., Gamalero, E., Berta, G., \& Massa, N. (2018). Combined bacterial and mycorrhizal inocula improve tomato quality at reduced fertilization. Scientia Horticulturae, 234, 160-165. 
Biçer ve ark., Hıyarda Kök Bakterisi (PGPR) ve Arbusküler Mikorizal Fungus (AMF) Aşılamalarının Farklı Sulama Seviyelerinde Bitki Gelişimi ve Verim Özelliklerine Etkileri

Bowles, T. M., Barrios-Masias, F. H., Carlisle, E. A., Cavagnaro, T. R., \& Jackson, L. E. (2016). Effects of arbuscular mycorrhizae on tomato yield, nutrient uptake, water relations, and soil carbon dynamics under deficit irrigation in field conditions. Science of the Total Environment, 566-567, 1223-1234.

Budak, B., Khalvati M. A., \& Özkan, Ş. S. (2017). The usage of native Arbuscular Mycorrhizal Fungi (AMF) in drought areas and low-input crop production systems. Adnan Menderes Üniversitesi Ziraat Dergisi, 14(2), 69-73.

Candido, V., Campanelli, G., D’Addabbo, T., Castronuovo, D., Perniola, \& M., Camele, I. (2015). Growth and yield promoting effect of artificial mycorrhization on field tomato at different irrigation regimes. Scientia Horticulturae, 187, 35-43.

Conversa, G., Lazzizera, C., Bonasia, A., \& Elia, A. (2013). Yield and phosphorus uptake of a processing tomato crop grown at different phosphorus levels in a calcareous soil as affected by mycorrhizal inoculation under field conditions. Biology and Fertility of Soils, 49, 691-703.

Çakmakçı, R. (2005). Bitki gelişimini teşvik eden rizobakterilerin tarımda kullanımı. Atatürk Üniversitesi Ziraat Fakültesi Dergisi, 36(1), 97-107.

Cakmakci, Ö., Cakmakci, T., Demirer Durak, E., Demir, S., \& Sensoy, S., (2017). Effects of arbuscular mycorrhizal fungi in melon (Cucumis melo L.) seedling under deficit irrigation. Fresenius Environmental Bulletin, 7513-7520.

Çalışkan, T., Aydın, A., Ortaş, İ., Sezen, M., \& Eken, M. (2017). Kısıtlı su ve mikoriza uygulamalarının genç Kütdiken limonunun gelişimi üzerine etkileri. Alata, 16(2), 28-36.

Çiylez, S., \& Eşitken, A. (2018). Mikoriza ve BBAR uygulamalarının çilekte büyüme üzerine etkileri. Selçuk Tarım ve Gıda Bilimleri Dergisi, 32(3), 361-365.

Dikici, M. (2019). Asi Havzası'nda (Türkiye) kuraklık analizi. Doğal Afetler ve Çevre Dergisi, 5(1), 22-40.

Doğan, S., \& Tüzer, M. (2011). Küresel iklim değişikliği ve potansiyel etkileri. Cumhuriyet Üniversitesi Iktisadi ve Idari Bilimler Dergisi, 12(1), 21-34.

Doğmuş Lehtijarvi, H. T., \& Lehtijarvi, A. (2006). Yarı kurak mıntıkalarda gerçekleştirilecek ağaçlandırma çalışmalarında mikorizalı fidan kullanımı ve önemi. Türkiye'de Yarı Kurak Bölgelerde Yapılan Ağaçlandırma ve Erozyon Kontrolu Uygulamalarının Değerlendirilmesi Çalıştayı, 7-10 Kasım, Nevşehir.

Ekici, M., \& Yıldırım, E. (2015). Bazı bitki gelişimini teşvik eden rizobakterilerin brokkoli (Brassica oleraceae L. var. italica) fide gelişimi ve fide kalitesi üzerine etkileri. Akdeniz Üniversitesi Ziraat Fakültesi Dergisi, 28(2), 53-59.

Ertek, A., \& Kanber, R. (2003). Effects of different irrigation programs on the lint out-turn of cotton under drip irrigation. Kahramanmaras Sutcu Imam University Journal of Engineering Sciences, 6, 106-116.

Ertek, A., Sensoy, S., Küçükyumuk, C. \& Gedik, I. (2004). Irrigation frequency and amount affect yield components of summer squash (Cucurbita pepo L.), Agricultural Water Management. 67, 63-76.

Faostat, (2017). Statistic Database. http://faostat.fao.org/. Erişim tarihi: 16 Eylül 2019.

Ghanbari Zarmehri, S., Moosavi S. G., Zabihi H. R., \& Seghateslami M. J. (2013). The effect of plant growth promoting rhizobacteria (PGPR) and zinc fertilizer on forage yield of maize under water deficit stress conditions. Journal of Applied Science, Engineering and Technology, 3(23), 3281-3290.

Gholamhoseini, M., Ghalavand, A., Dolatabadian, A., Jamshidi, E., \& Khodaei-Joghan, A. (2013). Effects of Arbuscular Mycorrhizal İnoculation On Growth, Yield, Nutrient Uptake and Irrigation Water Productivity of Sunflowers Grown Under Drought Stress. Agricultural Water Management, 117, 106-114.

Hassan, M. K., McInroy, J. A., \& Kloepper, J. W. (2019). The interactions of rhizodeposits with Plant Growth-Promoting Rhizobacteria in the rhizosphere: a review. Agriculture, 9(142), 1-13.

Howell T. A., Cuenca, R. H., \& Solomon K. H. (1990). Crop yield response. Manegement of farm irrigation systems. Chap. 5. An ASAE Monograph, St. Joseph, MI pp. 93-116.

James, L. G. (1988). Principles of Farm Irrigation Systems Design, John Wiley and Sons. Inc., New York.

Karipçin, M. Z., \& Şatır, N. Y. (2016). Su stresi koşullarında yetiştirilen marul sebzesinin verim ve besin içeriğine Arbusküler Mikorizal Fungus (AMF)'un etkileri. Yüzüncü Yıl Üniversitesi Tarım Bilimleri Dergisi, 26(3), 406-413.

Karlıdağ, H., Eşitken, A., Turan, M., \& Sahin, F. (2007). Effects of root inoculation of plant growth promoting rhizobacteria (PGPR) on yield, growth and nutrient element contents of leaves of apple. Scientia Horticulturae, 114, 16-20.

Karthikeyan, B., Joe, M. M., Jaleel, C. A. \& Deiveekasundaram, M. (2010). Effect of root inoculation with Plant Growth Promoting Rhizobacteria (PGPR) on plant growth, alkaloid content and nutrient control of Catharanthus roseus (L.) G. Don. Natura Croatica, 19(1), 205-212. 
Biçer ve ark., Hıyarda Kök Bakterisi (PGPR) ve Arbusküler Mikorizal Fungus (AMF) Aşılamalarının Farklı Sulama Seviyelerinde Bitki Gelişimi ve Verim Özelliklerine Etkileri

Kloepper, J. W., Ryu, C. M., \& Zhang, S. (2004). Induced systemic resistance and promotion of plant growth by Bacillus spp. Phytopathology, 94(11), 1259-1266.

Kokalis-Burelle, N., Kloepper, J. W., \& Reddy, M. S. (2006). Plant growthpromoting rhizobacteria as transplant amendments and their effects on indigenous rhizosphere microorganisms. Applied Soil Ecology, 31, 91-100.

Kotan, R. (2014). Faydalı bakterilerin tarımda kullanımı. Harman Time, 11, 44-48.

Küçükkılavuz, E. (2009). Küresel ısınmanın su kaynakları üzerine etkileri: Türkiye örneği. Yüksek Lisans Tezi, Harran Üniversitesi, Sosyal Bilimler Enstitüsü, Şanlıurfa.

Le, A. T., Pék, Z., Takács, S., Neményi, A., \& Helyes, L. (2018). The effect of plant growth-promoting rhizobacteria on yield, water use efficiency and brix degree of processing tomato. Plant Soil Environment, 64(11), 523-529.

Lucy, M., Reed, E., \& Glick, B. R. (2004). Application of free living Plant Growth-Promoting Rhizobacteria. Antonie van Leeuwenhoek, 86, 1-25.

Marulanda, A., Barea, J. M., \& Azco'n, R. (2009). Stimulation of plant growth and drought tolerance by native microorganisms (AM Fungi and Bacteria) from dry environments: mechanisms related to bacterial effectiveness. Journal of Plant Growth Regulation, 28, 115-124.

Miransari, M., Bahrami, H. A., Rejali, F., \& Malakouti, M. J. (2008) Using arbuscular mycorrhiza to alleviate the stress of soil compaction on wheat (Triticum aestivum L.) growth. Soil Biology Biochemistry. 40, 1197-1206.

Nadeem, S. M., Ahmad, M., Zahir, Z. A., Javaid, A., \& Ashraf, M. (2014). The role of mycorrhizae and plant growth promoting rhizobacteria (PGPR) in improving crop productivity under stressful environments. Biotechnology Advances, 32, 429448.

Narula, N., Deubel, A., Gans, W., Behl, R.K., \& Merbach, W. (2006). Paranodules and colonization of wheat roots by phytohormone producing bacteria in soil. Plant Soil Environment, 52(3),119-129.

Naseri, R., Moghadam, A., Darabi, F., Hatami, A., \& Tahmasebei, G. R. (2013). The effect of deficit irrigation and Azotobacter chroococcum and Azospirillum brasilense on grain yield, yield components of maize (S.C. 704) as a second cropping in western Iran. Bulletin of Environment, Pharmacology and Life Sciences, 2(10), 104-112.

Naveed, M., Hussain, M. B., Zahir, A. Z., Mitter, B., \& Sessitsch, A. (2014). Drought stres amelioration in wheat through inoculation with Burkholderia phytofirmans strain PsJN. Plant Growth Regulation, 73, 121-131.

Rozpadek, P., Rapata-Kozik, M., Wezowicz, K., Grandin, A., Karlsson, S., Wazny, R., Anielska, T., \& Turnau, K. (2016). Arbuscular mycorrhiza improves yield and nutritional properties of onion (Allium cepa). Plant Physiology and Biochemistry, 107, 264-272.

Sahin, U., Ekinci, M., Kiziloglu, F. M., Yildirim, E., Turan, M., Kotan, R., \& Ors, S. (2015). Ameliorative effects of plant growth promoting bacteria on water-yield relationships, growth, and nutrient uptake of lettuce plants under different irrigation levels. Horticultural Science, 50(9),1379-1386.

Saleem, M., Arshad, M., Hussain, S., \& Bhatti, A. S. (2007). Perspective of plant growth promoting rhizobacteria (PGPR) containing ACC deaminase in stress agriculture. Journal of Industrial Microbiology \& Biotechnolgy, 34(10), 635-648.

Samancıoğlu, A., Yıldırım, E., Şahin, Ü. (2016). Bitki gelişimini teşvik eden rizobakteri uygulamalarının farklı sulama seviyelerinde yetiştirilen lahanada fide gelişimi, bazı fizyolojik ve biyokimyasal özelliklerin etkisi. Kahramanmaraş Sütçü Imam Üniversitesi Tarım ve Doğa Bilimleri Dergisi, 19(3), 332-338.

Sezen, S. M., Yazar, A., \& Eker, S. (2006). Effect of drip irrigation regimes on yield and quality of field grown bell pepper. Agricultural Water Management, 81, 115-131.

Subramanian, K. S., Santhanakrishnan, P., \& Balasubramanian, P. (2006). Responses of field grown tomato plants to arbuscular mycorrhizal fungal colonization under varying intensities of drought stress. Scientia Horticulturae, (Amst.) $107,245-253$.

Turan, M., Ekinci, M., Yildirim, E., Güneş, A., Karagöz, K., Kotan, R., \& Dursun, A. (2014). Plant growth-promoting rhizobacteria improved growth, nutrient, and hormone content of cabbage (Brassica oleracea) seedlings. Turkish Journal of Agriculture and Forestry, 38, 327-333.

Tüfenkçi, Ş., Demir, S., Şensoy, S., Ünsal, H., Demirer, E., Erdinç, Ç., Biçer, Ş., \& Ekincialp, A., (2012). The effects of arbuscular mycorrhizal fungi on the seedling growth of four hybrid cucumber (Cucumis sativus L.) cultivars. Turkish Journal of Agriculture and Forestry, 36, 317-327.

TÜiK. (2018). Bitkisel Üretim İstatistikleri. https://biruni.tuik.gov.tr/medas/?kn=104\&locale=tr. Erişim tarihi: 16 Eylül 2019.

Van Loon, L. C. (2007). Plant responses to plant gowth-promoting rhizobacteria. European Journal of Plant Patholgy, 119, 243-254. 
Biçer ve ark., Hıyarda Kök Bakterisi (PGPR) ve Arbusküler Mikorizal Fungus (AMF) Aşılamalarının Farklı Sulama Seviyelerinde Bitki Gelişimi ve Verim Özelliklerine Etkileri

Walia, A., Metha, P., \& Chauhan, A. (2013). Effect of Bacillus subtilis strain CKT1 as inoculum on growth of tomato transplant under net house conditions. Procedings of the National Academy of Sciences India Section B: Biological Sciences, 84(1), 145-155.

Wang, C. J., Yang, W., Wang, C., Gu, C., Niu, D. D., Liu, H. X., Wang, Y. P., \& Guo, J. H. (2012). Induction of drought tolerance in cucumber plants by a consortium of three Plant Growth-Promoting Rhizobacterium strains. Public Library of Science One, 7(12), 1-10.

Yıldırım, M., Bahar, E., \& Demirel, K. (2015). Farklı sulama suyu seviyelerinin serada yetiştirilen kıvırcık marulun (Lactuca sativa var. campania) verimi ve gelişimi üzerine etkileri. Çanakkale Onsekiz Mart Üniversitesi Ziraat Fakültesi Dergisi, $3(1), 29-34$. 